\title{
A Study on Planned and Applied Irrigation Modules in Irrigation Networks: A Case Study at Büyük Menderes Basin, Turkey
}

\section{Cengiz Koç}

Department of City and Regional Planning, Faculty of Architecture, Muğla Sıtkı Koçman University, Muğla, Turkey

Email: cengizko9@gmail.com

How to cite this paper: Koç, C. (2016) A Study on Planned and Applied Irrigation Modules in Irrigation Networks: A Case Study at Büyük Menderes Basin, Turkey. Computational Water, Energy, and Environmental Engineering, 5, 112-122. http://dx.doi.org/10.4236/cweee.2016.54011

Received: September 12, 2016

Accepted: October 23, 2016

Published: October 27, 2016

Copyright $\odot 2016$ by author and Scientific Research Publishing Inc. This work is licensed under the Creative Commons Attribution International License (CC BY 4.0).

http://creativecommons.org/licenses/by/4.0/

(c) (i) Open Access

\begin{abstract}
In this study, irrigation modules calculated in planning and actualized operational stage of the irrigation networks are examined. Irrigation module used irrigation networks is a constant discharge parameter, meeting the needs of irrigation water requirement smonthly of crops in one hectare of irrigation area and it is a constant discharge flowing continuously for a month. Extent of the overlapping between the irrigation planning module and the operation module actualized during the operational stage of the irrigation network depends on changes in the cropping patterns, differences in the effects of field irrigation methods used by farmers on the capacity of the constructed system, the increases or decreases in the water demands depending on the irrigation period, as well as the extent of sustainability according to the selected operation method. A2 irrigation area of Aydin plain irrigation network, locating in the Büyük Menderes basin, Turkey is selected as study area, with an area of 2500 ha. Irrigation planning module calculated for this network is $q=1.16 \mathrm{l} / \mathrm{s} / \mathrm{ha}$ and it has been designed as per the supply demand operation method. For the study; actualized irrigation module in the operation stage has been compared with the planning irrigation module by using Excel software and taking parameters such as actual crop pattern and percentage distributions, actualized irrigated areas, irrigation networks and water distribution, water intake of irrigation networks which have been calculated without operation losses, as well as with $5 \%, 10 \%$, and $15 \%$ operation losses. The July operation module calculated for the examined irrigation network generally conforms to the planning module, as it has received the values close to or below the value of irrigation planning modules.
\end{abstract}

\section{Keywords}

Irrigation Network, Irrigation Module, Operational Method, Irrigation Water, Turkey 


\section{Introduction}

A well planned distribution network which has been turned into a project for irrigation purposes, should deliver the necessary amount of water needed within the desired timing, without causing problems to the operational and management requirements. Creating suitable projects of irrigation systems in accordance reveals some important results. These would be classified as health of the local people, wasted natural resources, water pollution, operational security and economic factors. Economic factors include the economic life of the irrigation system, the economic benefits of irrigation as well as the irrigation costs. Irrigation systems made with weak projects, where the water is not used homogeneously, causes water and the chemicals applied with water to go to waste. As a result, some areas are over-watered, while some areas are not sufficiently irrigated. Even though irrigation managers may apply the right amount of water, especially due to water stress in incompletely irrigated areas, there will be yield and quality reductions, and in extremely irrigated areas (due to the washing of water and chemicals), it can lead to reduction in efficiency and quality.

The most important investment share in irrigation projects which require large investments for agricultural fields is the construction of water transmission and distribution channels. In our country, the ongoing construction of irrigation networks by public institutions are the necessary facilities to meet water needs in a balanced manner for the development of crops in agricultural areas. The function of main, secondary (backup) and tertiary water transmission and distribution systems is to transport irrigation water to the plant from the water intake point. To examine the water source in detail and to acquire the necessary design parameters generally requires identifying the distribution areas of plants which are to be grown with plant density and to prepare the starting location of the networks. This case also encompasses the required structure of the type, capacity, the size of main channels, regional conditions, the water level, flow control, as well the shape and size of the dominant area [1].

Differences in the crop patterns within the area served by the water resources can bring about irregularities in the total project area. Peak resource utilization for different parts of the project area may occur at different times. In this manner, the specified resource plans, mainly from resource requirements, can vary quite a lot and constantly uses monthly data source [2]. Since the plant density and their variations can cause differences in resource requirements, this initiates some flexibilities to be maintained in the irrigation program magnitude. Therefore, during the planning stages of a project, the normal estimate is that in order to operate effectively it takes many years. The resulting increase in resource requirements has to be covered by improvements in the irrigation operations of fields and improvement in water savings.

Different strategies are used in water distribution and control of irrigation networks throughout the world. Outdated irrigation network design types are observed in both developed and developing countries. Many years ago many irrigation projects in the United States, Western Europe and Australia were inefficient in terms of energy and water use, and required urgent modernization [3]. In most developing countries, an in- 
flexible water distribution system is used where the flow rate and the frequency is fixed to the water supply. This application is still applied in various irrigation systems. In this scenario, water users do not have much flexibility in terms of continuity of water supply. They use it when water is available, regardless of whether plants need water or not, and thus they will be wasting water [4]. There are several types of water distribution methods available. However, fundamentally they can be divided into two basic factors, including demand and supply methods. Although formally the demand method is utilized in Turkey, the supply method is actually used as well in many projects. Irrigation networks are designed according to the crop patterns set in the planning report, but in practice they may show annual changes in crop patterns and create significant problems during the operational processes [5]. When physical, socio-economic and technical knowledge base is taken as a baseline; different distribution types, such as rotational, continuous flow and demand distribution types are implemented for years. The rotation program in irrigation channels are used in large irrigation schemes of developing countries such as China, Pakistan and India [6].

This study, which was conducted in western of Turkey, is at the Aydin plains irrigation A2 project area which is located in the Büyük Menderes Basin. The investigation has focused on the overlapping of planning irrigation module with the operational irrigation modules calculated with crop patterns, without operational losses and with 5\% to $10 \%$ operational losses considered. The planning irrigation module $\left(\mathrm{q}_{\mathrm{P}}=1.16 \mathrm{l} / \mathrm{s} / \mathrm{ha}\right)$ is calculated with preplanned crop patterns, crop areas, the water consumption of plants and irrigation losses taken as a base material.

\section{Material and Method}

\subsection{Material}

In this study, A2 İrrigation Area, which was constructed by Public Water Works and which is located in the Lower Great Menderes basin irrigation area in Aydin was taken. The study area is located at $37^{\circ} 51^{\prime}$ north latitude and at $32^{\circ} 52^{\prime}$ east longitude, in a region bounded near about $3 \mathrm{~km}$ south of the center of Aydin province and between Büyük Menderes River, which includes the area bounded by İncirliova Osmanbükü village in the section extending to the land (Figure 1). A2 gross irrigated area is 2500 ha, and the net area is 2158 ha. An important part of the parcels that make up the irrigation area has a surface area smaller than 10 decare. The effective crop pattern in the irrigated area is mainly cotton, while corn, grain, tomatoes, forage and II. product corn plants are cultivated. The cultivation of maize products in the planning stages consist of $48 \%$ cotton, $16 \%$ corn, $13 \%$ vegetables, $10 \%$ forage crops, fruit $6 \%, 4 \%$ II corn products and 3\% maize seedlings. A2 Irrigation area in Aydin Plain is located in the flood area of the Büyük Menderes River. The flow rate of the Büyük Menderes River is very low and the materials which are transported in the river are clay-silt size. Therefore, geological structure of the region and the study area is made of alluvium material [7].

The region is influenced by the Mediterranean climate and as a result winters are mild and very wet, and summers are hot and dry. Over the years the highest tempera- 


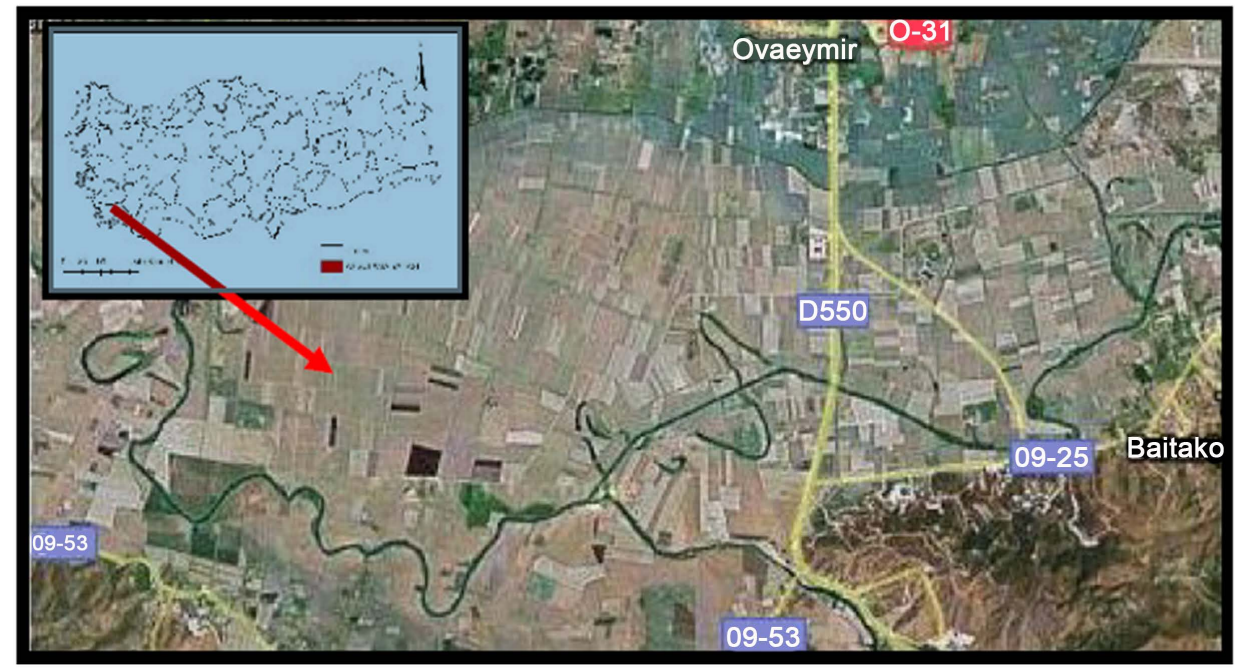

Figure 1. The location of A2 irrigation area in Turkey [8].

ture recorded was $43.8^{\circ} \mathrm{C}$, the lowest temperature recorded was $3.5^{\circ} \mathrm{C}$, while the average temperature was $17.7^{\circ} \mathrm{C}$. The average height above sea level of the irrigation area is $32.50 \mathrm{~m}$, and the estimated annual rainfall is $656.1 \mathrm{~mm}$. The Water supply comes from Büyük Menderes River, and the storage facilities used are Adıgüzel and Kemer dams. Water consumption values of planned design and actual plant application in the irrigation field was calculated by Blaney-Criddle method [9].

The total length of the A2 main irrigation channel in the study area is 11,351 m, 9007 meters comprises of classic trapezoidal channels, canals, and 2344 meters comprises of small channels. The main channel flow is $2780 \mathrm{~m}^{3} / \mathrm{s}$. 28 pieces of secondary (backup) channel was built with a total length of $56,395 \mathrm{~m}$ connected to the main channel A2. Tertiary total number of channels is 34 and the total length is 39,001 meters. All of the secondary and tertiary canals were built in the flume system. Table 1 gives the main irrigation channel sections and hydraulic properties for A2 main irrigation channel [10]. The irrigation efficiency of irrigation projects in A2 is 54\%. Water transmission efficiency was determined as $90 \%$, and the field irrigation efficiency was determined to be $60 \%$ [8]. Average washing water requirement needed for the research field was calculated as 0.24 [11].

\subsection{Method}

\subsubsection{Irrigation Planning Module}

Irrigation module is the most important element of an irrigation network sizing. This is because the design capacity of the channel is calculated by the formula $Q=A_{\text {net }} \times q$ $(1 / s)$.The irrigation module which depicts the need for water is determined according to parameters such as irrigation of the field; cropping patterns, planting area rate, evapotranspiration, climatic conditions, soil properties, irrigation losses (transmission + field irrigation losses); and it is defined as the amount of water in liters per second given in a continuous manner for 24 hours and 30 days to the terrain during the month where maximum demand occurs. 
Table 1. Hydraulic properties and cross sections pertaining to A2 main irrigation channel.

\begin{tabular}{|c|c|c|c|c|c|c|c|c|c|c|c|}
\hline $\begin{array}{l}\text { Cross } \\
\text { section } \\
\text { No } \\
\end{array}$ & $\begin{array}{l}\text { Slope } \\
\text { (j) }\end{array}$ & $\begin{array}{c}\text { Flow } \\
\text { Rate (Q) } \\
\left(\mathrm{m}^{3} / \mathrm{s}\right)\end{array}$ & & & & $\mathrm{Km}$ & & & & $\begin{array}{c}\text { Base } \\
\text { Width } \\
(\mathrm{m})\end{array}$ & $\begin{array}{c}\text { Water } \\
\text { Height } \\
(\mathrm{m})\end{array}$ \\
\hline 1 & 0.0001 & 2.778 & 0 & + & 025 & - & 1 & + & 874 & $\mathrm{~d}$ & 1.28 \\
\hline 2 & 0.0001 & 2.692 & 1 & + & 874 & - & 2 & + & 607 & 2.20 & 1.26 \\
\hline 3 & 0.0001 & 2.608 & 2 & + & 607 & - & 4 & + & 000 & 2.20 & 1.24 \\
\hline 4 & 0.0001 & 1.938 & 4 & + & 000 & - & 5 & + & 536 & 1.60 & 1.00 \\
\hline 5 & 0.0001 & 1.569 & 5 & + & 536 & - & 7 & + & 580 & 1.40 & 0.94 \\
\hline 6 & 0.0001 & 1.161 & 7 & + & 580 & - & 8 & + & 000 & 1.40 & 0.85 \\
\hline 7 & 0.0001 & 1.161 & 8 & + & 000 & - & 9 & + & 007 & 1.20 & 0.85 \\
\hline 8 & 0.0001 & 0.820 & 9 & + & 000 & - & 11 & + & 351 & $\begin{array}{c}\text { Type } 1000 \\
\text { Cahnnel } \\
\text { (Exit Type) }\end{array}$ & \\
\hline
\end{tabular}

If the irrigation water which flows for a month is due to the need of the farming irrigation, then this module is called the farm irrigation scheduling module. If this water which flows for a month is due to diversion of the irrigation water need, then this module is called the irrigation planning module. The irrigation planning module is calculated as $1.16 \mathrm{l} / \mathrm{s} /$ ha for the study area [12].

Planned farming irrigation module $(\mathrm{l} / \mathrm{s} / \mathrm{ha})$ :

$$
\frac{\mathrm{Ut} \times 10^{4}}{(30 \text { veya } 31) \times 24 \times 60 \times 60}=\mathrm{qç}
$$

Planned irrigation module (l/s/ha):

$$
\frac{U k \times 10^{4}}{(30 \text { veya } 31) \times 24 \times 60 \times 60}=q p
$$

$U t \times 10^{4}:$ Monthly farm irrigation water requirement per hectare $(\mathrm{mm})$

$U k \times 10^{4}:$ Monthly diversion irrigation water requirement per hectare $(\mathrm{mm})$

\subsubsection{Operational Irrigation Module}

Operational irrigation module is the function of the irrigation water to be utilized per the real crop pattern, the water with and without losses, monthly processes and the actual irrigated area in the irrigation region.

$$
\frac{W_{\mathrm{k}}}{(30 \text { veya } 31) \times 24 \times 60 \times 60} \times 1000=S
$$

Operational irrigation module $(\mathrm{l} / \mathrm{s} / \mathrm{ha})$

$$
\frac{S}{A_{f}}=q i
$$

$W_{k}$ amount of water intake to the channel ( $\mathrm{m}^{3} /$ month); $S$, amount of water intake to the channel (1/s); $A_{f}$ actual irrigated area in the irrigation region; $q i$, operational irrigation module for that month $(1 / \mathrm{s} / \mathrm{ha})$ 


\section{Study Data and Discussion}

In this research, the conformity of the irrigation module which is calculated according to actual plant patterns, the irrigation module calculated per intake water without losses, the irrigation modules as per $5 \%$ to $10 \%$ losses during operation, versus the planning irrigation module $\left(\mathrm{q}_{\mathrm{P}}=1.16 \mathrm{l} / \mathrm{s} / \mathrm{ha}\right)$ considered crop pattern in the planning stages of the irrigation network, planting area, evapotranspiration and irrigation losses (transmission + field) is calculated. It can also be said that the irrigation planning module and the actual irrigation module has been compared for the project area. After the operation has started in the project area, the calculated irrigation module per the years 1999-2014 for the month of July $\left(\mathrm{q}_{\mathrm{T}}\right) 1.01$ to $1.15 \mathrm{l} / \mathrm{s} / \mathrm{ha}$, for the month of August $\left(\mathrm{q}_{\mathrm{A}}\right)$ is 0.61 to 1.09 range is realized (Figure 2). During the study, the years of 2007-2008 have not been taken into consideration in the calculation of the irrigation module as they have been very dry years with heavy drought. The highest operational irrigation has taken place in July 2002 within all the years studied. However, this value is below the irrigation planning module. In August 2002 it has been calculated as $1.09 \mathrm{l} / \mathrm{s} / \mathrm{ha}$. Planning for the highest plant irrigation module is calculated based on water consumption in July, as it is the time where the highest water consumption takes place. However, in order to make an accurate assessment, the irrigation modules for August is also calculated.

It is observed that there is no problem in terms of irrigation module values, which have been calculated according to the planned and actual cropping patterns. However, having a little higher planned module versus the realized cropping patterns has caused the channel capacity to be increased, but in terms of construction economics, this has led to only very few negative aspects. However, since planning for irrigation module is based on the July irrigation module, the 1.15 and $1.16 \mathrm{l} / \mathrm{s} /$ ha values have an overlap with a ratio of 0.99 , thus causing construction economics to have negligible negative effect.

Without taking into account the channel operational losses (the main channel drain outlet, secondary and tertiary canal breaks), and under the assumption that all of the water taken into the channel is utilized in irrigation; the calculated irrigation modules for the year examined is found for the month of July as $\left(\mathrm{q}_{\mathrm{T}}\right) 1.07$ to $1.25 \mathrm{l} / \mathrm{s} / \mathrm{ha}$, and for

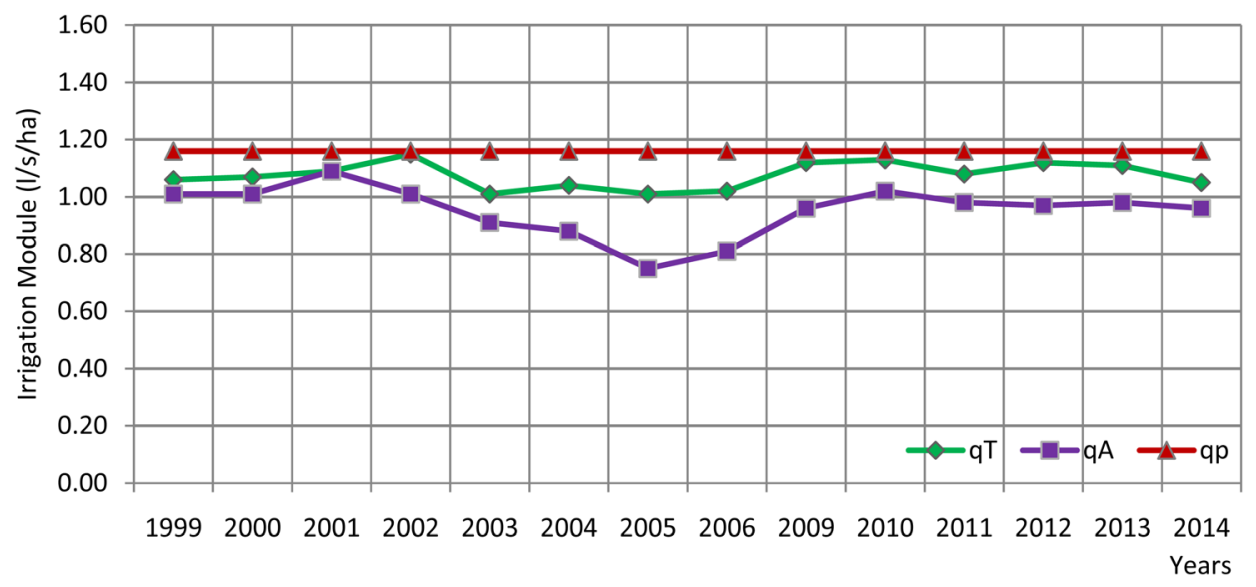

Figure 2. Irrigation module calculated as per crop patterns. 
as August $\left(\mathrm{q}_{\mathrm{A}}\right) 0.98$ to $1.11 \mathrm{l} / \mathrm{s} /$ ha (Figure 3 ). Since the calculations are conducted with July planning module taken into account, the July 2001 irrigation channel module with value of $1.25 \mathrm{l} / \mathrm{s} /$ ha is slightly above the planning module. The irrigation modules for the years of 1999-2000-2001-2002-2003-2009 for the month of July have given values above the value of the planning module. However, it can be stated that when some amount of water taken into the channel drain outlets, and also to secondary and tertiary canal breaks, then the high July modules will not be creating a problem. The highest module that took place in August for the years under the highest module is realized as $1.16 \mathrm{l} / \mathrm{s} / \mathrm{ha}$, which is below the planned irrigation module. Since the water taken into the channel can't be utilized without some losses, then it won't be a problem for the irrigation modules calculated under these conditions.

The operational irrigation module calculated with the assumption of $5 \%$ operational losses in waters taken into the channel, has shown a variation of $1.02-1.19 \mathrm{l} / \mathrm{s} / \mathrm{ha}$ with $\left(\mathrm{q}_{\mathrm{T}}\right)$ in the month of July and $\left(\mathrm{q}_{\mathrm{A}}\right)$ has shown a variation of $0.90-1.12 \mathrm{l} / \mathrm{s} / \mathrm{ha}$ in the month of August (Figure 4).

For the examined period, just in July 2011, the operational irrigation module with the value of $1.19 \mathrm{l} / \mathrm{s} /$ ha has been realized as 1025 times more than the planning module. This value can be omitted since it is not an amount which can create a trouble for the operations. When the calculated data is taken into account, there is no problem observed between the calculated irrigation module at planning stage and the irrigation module calculated with $5 \%$ operational losses. Since the irrigation network is designed as per the operational demand method, the problems that may crop up can be eradicated by reflecting the current demand to the irrigation planning during the operation of the system. Furthermore, the changes in the plant patterns during the agricultural farming at the irrigation area may prevent demand pileup.

The operational irrigation module which has been calculated with the assumption of $10 \%$ operational losses in waters taken into the channel has shown a variation of 0.97 $1.10 \mathrm{l} / \mathrm{s} /$ ha with $\left(\mathrm{q}_{\mathrm{T}}\right)$ in the month of July. Furthermore, $\left(\mathrm{q}_{\mathrm{A}}\right)$ has shown a variation of $0.91-1.06 \mathrm{l} / \mathrm{s} /$ ha in the month of August (Figure 5).

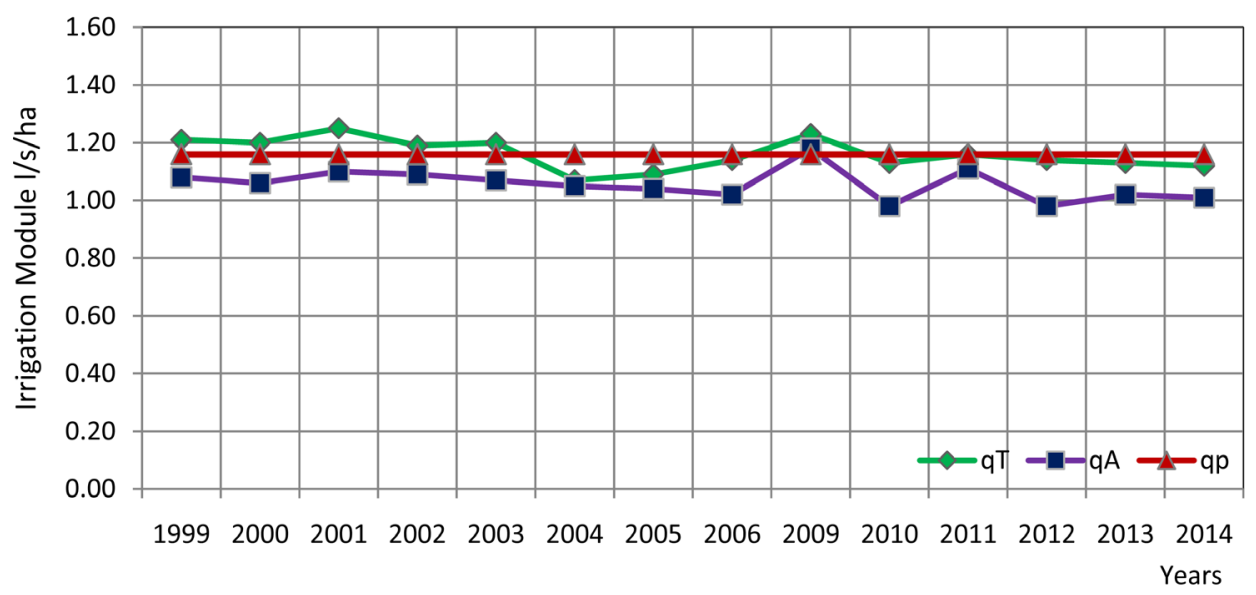

Figure 3. Module calculated as per intake of water without losses. 


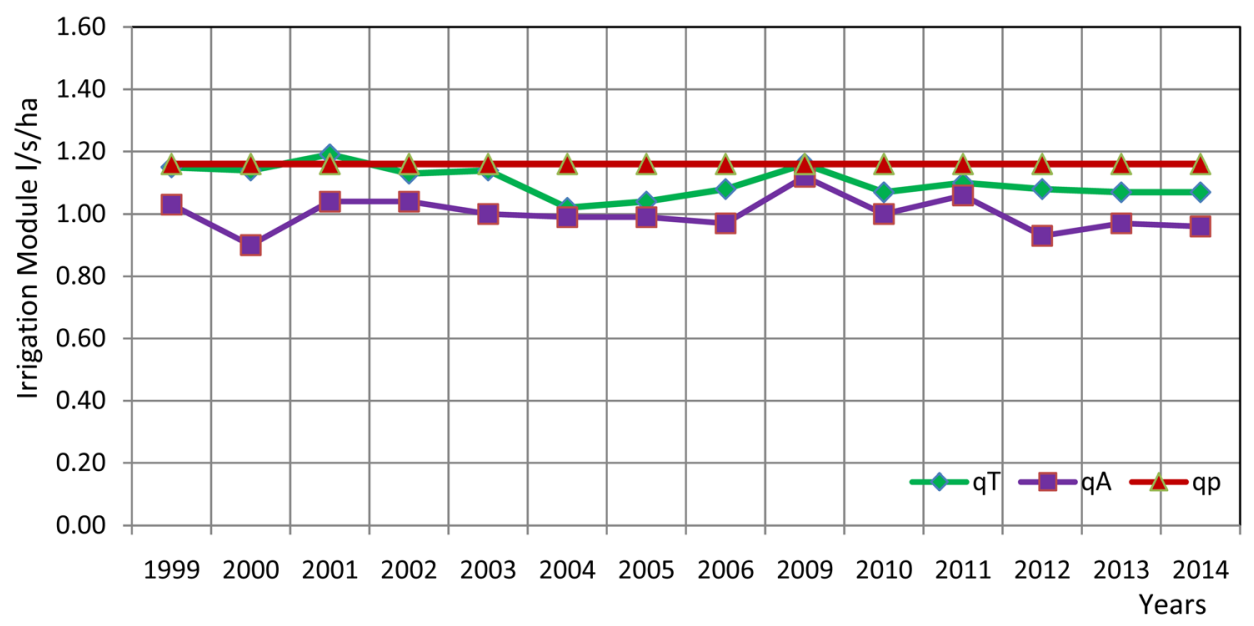

Figure 4. Calculated module with 5\% losses during water intake.

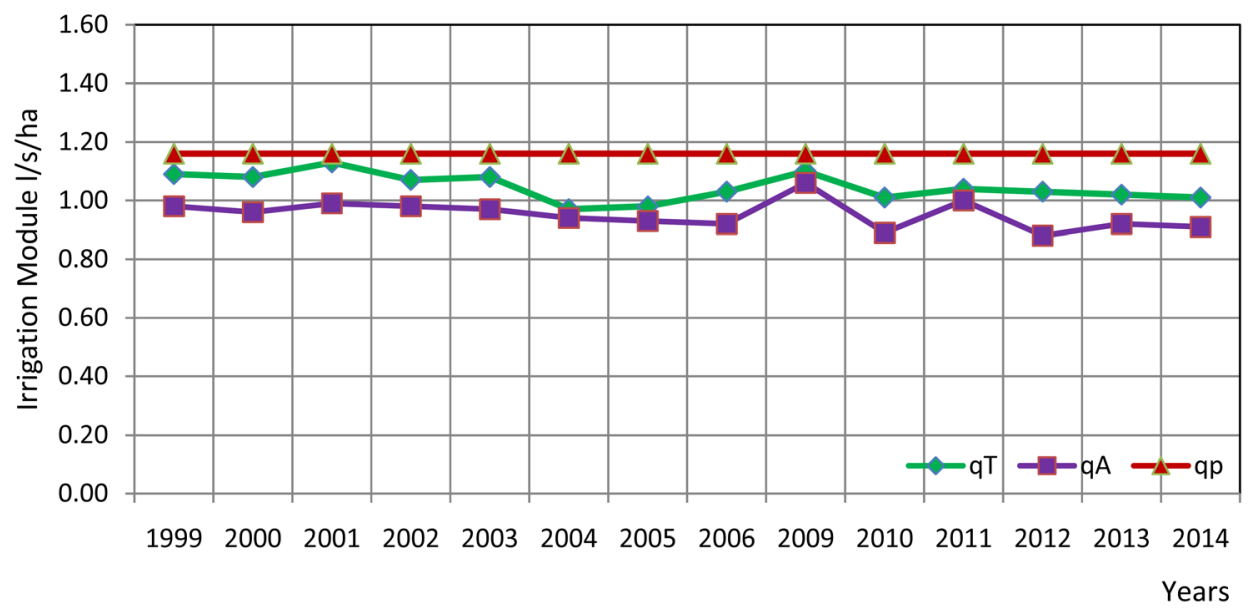

Figure 5. Calculated module with 10\% losses during water intake.

The calculated operational module values have been realized below the planning module values. As per this assumption, there is no problem observed with irrigation operations. However, a design which is incorporated with this assumption can reduce the construction costs to a certain extent. When these assumptions are taken into account, it becomes necessary to have a more planned water distribution, which reduces the channel losses. The planning by taking into account water intake channel capacity can remove problems related to module and design flow.

\section{Conclusions and Recommendations}

There are no problems found in between the calculated irrigation module at the planning stage and the operational irrigation module calculated with the actual cropping patterns, the intake water taken into the channel without losses as well as the water intake with $5 \%$ and $10 \%$ operational losses. In this context, there is also no problem found in terms of the design flow of the entire channel system in the irrigation network. This case leads to the conclusion that the work done during the planning stages of the 
irrigation network were very attentive and worth appreciating. This reinforces the statement once again that good planning always leads to a good project, and a good project creates the good conditions for its operation. The overlapping of planning values with the operational values shows the success of planning and it allows for the realization of the expected benefits from the system within the expected time frame.

Whether the calculated operation irrigation module is lower or higher than the planned irrigation module carries an importance related to irrigation system operations, system design (capacity, dimensions) and for construction costs. If it is lower than the planned irrigation module, then this can cause a lower amount of water to be dispersed to unit area per unit of time. This situation will mean that the crops growing in the project area will not have sufficient amount of irrigation water. If it is higher than the planning module, then this causes more water to be released to the unit area per unit time. This situation can be caused by the change of crop cultivation pattern over time in the project area or due to reduction of agricultural lands caused by various reasons. This condition can limit the irrigation of plants grown within the project area to be lesser then the designated intervals. Therefore, it is not desirable for the operational irrigation module to have either higher or lower values then the planned irrigation module. In these types of situations, in accordance with the overlap ratio, the problems can be eliminated by taking precautions within the flexibility of operational irrigation programs and demand management.

Since the irrigation planning module is related to plant patterns in the project area as well as to the crop patterns, its density and crop fields; it is essential to carefully identify the best crop pattern for the project area and it must be determined close to real conditions. Local cultivation habits and plants which don't conform to market conditions should not be taken into consideration.

Since the planned irrigation system directly determines the system design and in this context, it affects the construction costs which require careful field and office work. Specifically, more parameter based on the calculation of water consumption values for plant-cultivating plants considered in the project area should be encouraged to use the empirical method. Farming habits of the person conducting agriculture and socio-economic structures in the region should be taken into consideration for the determination of the efficiencies of field irrigation method and efficiency of irrigation water application. These are the direct project criteria, and thus this must be executed kind of thinking must be abandoned and better suggestions as per the region and conditions present.

Implementation of land consolidation and land leveling work in the field of research, and to design the tertiary intervals at a maximum range of $200 \mathrm{~m}$ in this context provides a positive contribution to the overlap of the planning and operation of the module. Therefore, the implementation of land consolidation and land leveling before the construction of irrigation networks in the irrigation project area will increase the success of the project [13].

The calculation of operations feedback module for irrigation scheduling criteria 
would provide feedback which will assist in the change of planning or project criteria or it will contribute to making it better. As in every business system, feedback and performance data must be calculated, it should be evaluated, and then it should especially be compared with the planning criteria.

The irrigation planning module which is calculated by taking into account certain assumptions which are true, attentive, and related to climate change and business conditions, actually is a module utilized for the determination of the direct channel capacity (design flow) and for better evaluation of the available financial resources for the construction of irrigation networks. Thus, it will have an effect on irrigation network construction economy and it will help to provide the expected benefits for the desired duration.

The changes (reduction-increase) in the actual irrigated areas in the study area affect the operational irrigation module, and this situation can cause discomfort or as an alternative provide relief to the irrigation network management.

The accurate and precise measurement of irrigation waters of the channel will allow the calculation of a healthier operational module value. Therefore, it will contribute to achieving the correct and reliable data for the frequency of water intake by remote sensing methods.

The appropriate irrigation module has to be calculated as depending on whichever farm irrigation methods will be implemented in the irrigation of the area (border, furrow, sprinkler, drip). If there is going to be a change in the method, then a new module must be recalculated. Since the water transmission and field application efficiency of irrigation can change, as a result the irrigation module will also vary.

\section{References}

[1] Koç, C. (1990) Design and Operation of Irrigation Systems. General Directorate of State Hydraulic Works (DSI). Ministry of Forestry and Hydraulic Works. DSI Technical Bulletin, 72, 28-34.

[2] Burt, C.M. (1999) Essential Water Delivery Policies for Modern On-Farm Irrigation Management. In: Irrigation Scheduling. From Theory to Practice. Proceedings ICID/FAO Workshop, September 1999, Rome, Water Report No. 8 FAO, Rome, Italy.

[3] Plusquellec, H. (2002) How Design Management and Policy Affect the Performance of Irrigation Projects. Emerging Modernization Procedures and Design Standards. FAO. Bangkok.

[4] Reddy, M. (2004) Technical Management of Irrigation Systems. In: Operation of Irrigation Conveyance Systems. International Capacity Building Program on Participatory Irrigation Management. INPIM Train Module. 5-15 December 2004, Menemen.

[5] Tekinel, O. (2001) Participatory Approach in Planning and Management of Irrigation Systems. Advanced Short Course on Appropriate Modernization and Management of Irrigation Systems, 2-15 September, 2001, Kahramanmaras University, Turkey.

[6] Maffiotra, S.P. (1982) Warabandi System and Its Infrastructure. Central Board of Irrigation and Power. New Delhi.

[7] DSI (State Hydraulic Works) (2002-2006) Report of Planning İrrigation Water Distribution in Aydın Plain Network. General Directorate of State Hydraulic Works (DSI). Ministry of 
Forestry and Hydraulic Works. 21. Rural Directorate of State Hydraulic Works. Aydın. 125 p.

[8] Google Earth Pro 6.2.1.6014 (beta) (2011) Eagan Region, ON Turkey 37051' North Latitude and at $32^{\circ} 52^{\prime}$ East Longitude Borders and Labels; Places Layers. NOAA, Digital Globe 2013.

[9] Koç, C. (1998) Büyük Menderes Havzası Sulama Şebekelerinde Organizasyon-Yönetim Sorunlarıve Yeni Yönetim Modelleri Üzerine Araştırmalar. Doktora Tezi. Ph.D. Thesis, (Unpublished), Ege Üniversitesi Ziraat Fakültesi. Tarımsal Yapılarve Sulama Anabilim Dalı, İzmir, $183 \mathrm{~s}$.

[10] DSİ (State Hydraulic Works) (1992) Aydın Plain Network Facility Introduction Sheet. General Directorate of State Hydraulic Works (DSI). Ministry of Forestry and Hydraulic Works. 21. Rural Directorate of State Hydraulic Works. Aydın. 105 p.

[11] Koç, C. (2008) The Environmental Effects of Salinity Load in Great Menderes Basin Irrigation Schemes. Environmental Monitoring and Assessment, 146, 479-489. http://dx.doi.org/10.1007/s10661-008-0478-0

[12] DSİ (State Hydraulic Works) (1984) Planning Report of Aydın Plain Irrigation. General Directorate of State Hydraulic Works (DSI). Ministry of Forestry and Hydraulic Works. 21. Rural Directorate of State Hydraulic Works. Aydın. 450 p.

[13] Koç, C. (2006) An Investigation on Water Delivery Methods Actualized in Practice and Suggested in Project of Irrigation Schemes. International Symposium on Water and Land Management for Sustainable Irrigated Agriculture in Memory of Prof. Dr. Osman Tekinel. Sütçü Imam University, RIHN, CIHEAM, TÜBİTAK, Çukurova University, Adana, Abstract Page 289 Turkey.

\section{Submit or recommend next manuscript to SCIRP and we will provide best service for you:}

Accepting pre-submission inquiries through Email, Facebook, LinkedIn, Twitter, etc. A wide selection of journals (inclusive of 9 subjects, more than 200 journals)

Providing 24-hour high-quality service

User-friendly online submission system

Fair and swift peer-review system

Efficient typesetting and proofreading procedure

Display of the result of downloads and visits, as well as the number of cited articles

Maximum dissemination of your research work

Submit your manuscript at: http://papersubmission.scirp.org/

Or contact cweee@scirp.org 